\title{
English as a native language, World Englishes and English as a lingua franca-informed material: acceptance, perceptions and attitudes of Chinese English learners
}

\author{
Jinghui Si \\ School of Humanities, Languages and Social Science, Nathan campus, Griffith \\ University, 170 Kessels Road QLD 4111, Australia. \\ Email: jinghui.si@griffithuni.edu.au
}

\begin{abstract}
This article aims to explore whether well-attested findings of World Englishes (WE) and English as a lingua franca (ELF) research have been included in Chinese English language teaching (ELT) materials and how Chinese English learners perceive English as a native language (ENL), WE and ELF-informed materials. The study was carried in the Chinese Business English Program. Results from questionnaires and interviews suggest that: there is no significant move to include linguistic and cultural diversity; ENL-informed materials are perceived as essential while WE-informed materials are perceived as necessary only at the advanced level; the current materials include inauthentic ELF scenarios, which might provide misleading information to English learners; and native cultures, non-native cultures and learners' home culture are recommended to be included in ELT materials. In the light of these findings, suggestions for the design and use of ELT materials in the Chinese context are offered.
\end{abstract}




\section{Introduction}

The global spread of English has been conceptually interpreted and empirically investigated from different research frameworks, among which are World Englishes (WE) and English as a lingua franca (ELF). Since the proposal of the 'three circles' model (Kachru, 1990), WE research has made great advances in unpacking how English is institutionalized and nativized in the Outer and Expanding Circle countries (D’Angelo, 2005; Kirkpatrick \& Xu, 2002; Ma \& Xu, 2017; Pingali, 2009; Tan \& Low, 2014). Meanwhile, the role of ELF, referring to 'any use of English among speakers of different first languages for whom English is the communication medium of choice, and often the only option' (Seidlhofer, 2011, p. 7), seems undisputable especially in the business area (i.e. English as business lingua franca). ELF research has uncovered an ad hoc and creative use of English in multilingual settings, indicating that ELF users can adapt their Englishes to meet their own communication needs (Cogo \& Dewey, 2012; Jenkins, Cogo, \& Dewey, 2011; Seidlhofer, 2011). The two threads of research have challenged the monolithic view of English in English language teaching (ELT) and thus problematized the English as a native language (ENL)-informed teaching paradigm, which remains commonly practised in the fields of English as a foreign language (EFL) and which remains influential in second language acquisition (SLA) (Dogancay-Aktuna \& Hardman, 2018). In contrast to ENL-informed teaching, where learners are expected to make errors, as defined by the use of nonstandard forms in the process of approximating idealized native speakers, both WE and ELF-informed teaching regard 'errors' as possible variants (De Costa \& Crowther, 2018). Therefore, instead of an exclusive focus on Standard English, represented by American English and British English in ENL-informed teaching, WE and ELF-informed teaching is grounded in a pluricentric view of English and collectively accentuates the importance of linguistic and cultural diversity (Galloway, 2017; Jenkins, 2006, 2012; Kirkpatrick, 2012; Matsuda, 2003, 2012a, 2012b, 2018; Xu, 2018).

Meanwhile, the global spread of English has manifested itself in local English 
language policies (Spolsky, 2004). In the Chinese context specifically, the Chinese Ministry of Education issued an English language policy in 2001 which required the teaching of English from primary school level $(\mathrm{Hu}, 2008)$. English thereafter has become a compulsory subject from primary school to higher education. With the penetration of English in the Chinese education system, China was assumed to have the largest number of English learners worldwide (Bolton, 2006; Crystal, 2008). Consequently, how to better teach this large number of English learners has been an interest of EFL/SLA, WE and ELF scholars at home and abroad (Bolton, Botha, \& Zhang, 2015).

Wright and Zheng (2017) argued that the movement in ELT in the last decades 'only changed the "how" of what was to be learnt not the "what" (p. 515). WE and ELFinformed teaching, which tends to change 'what' should be taught and learnt, has naturally caused tensions and concerns over what 'English' should be presented to English learners in ELT. This study aims to address the tensions and concerns by investigating Chinese English learners' acceptance, perceptions and attitudes towards ENL, WE and ELF-informed learning materials.

\section{ENL, WE and ELF-informed learning materials}

An in-depth analysis of English textbooks in different contexts has resulted in a similar finding; that is, the dominance of ENL, its users and cultures (Kopperoinen, 2011; Matsuda, 2002; Ren \& Han, 2016; Sherman, 2010; Shin, Eslami, \& Chen, 2011; Song, 2013; Taylor-Mendes, 2009; Tomlinson \& Masuhara, 2013; Vettorel \& Lopriore, 2013; Yim, 2007). However, the use of these ENL-informed learning materials has been challenged in the following ways:

(1) Non-native English speakers far outnumber native English speakers (Crystal, 2006). English communication happens more often among non-native English speakers rather than between non-native and native English speakers. Therefore, the ideal native speaker that is promoted in ENL-informed materials is inappropriate as a target for most English communications. 
(2) English is owned and developed by all English users not just by the so-called native English speakers (Kirkpatrick, 2012). The need for native-speakerism that is promoted in ENL-informed materials is thus unnecessary (Marlina, 2017).

(3) A learner's first language and home culture should be regarded as a " "badge" of linguistic and culture heritage and identity" instead of a "'baggage" of burden and negativity' (Xu, 2017, p. 704).

The criticism towards ENL-informed materials has inspired proposals for linguistic and cultural diversity in learning materials. Some researchers have highlighted the need for the inclusion of localized English (Jenkins, 2015; Marlina, 2017; Matsuda, 2003; $\mathrm{Xu}, 2017)$, which could reflect the actual use of English in a local context (Li, 2007), facilitating the development of an awareness of language variations (McKay, 2018) and helping students value their first languages (Matsuda, 2012a). This inclusion requires a systematic codification of linguistic features of a localized variety of English ( $\mathrm{He} \& \mathrm{Li}$, 2009), which is supported in attitudinal research carried out in the Chinese context. According to $\mathrm{He}$ (2017), Chinese college students believe that systematically codified linguistic features of China English should be incorporated into teaching materials as a supplement to ENL-informed learning materials. Going a step further, Marlina (2017) pointed out that interviewees in his study had already employed China English-related materials such as China Daily and Xinhua Daily in their teaching.

Meanwhile, researchers have suggested the incorporation of materials illustrating the authentic use of ELF in multilingual settings (Kirkpatrick, 2012). By doing so, learners could be informed about the ad hoc and creative use of English, understand how meanings are negotiated and communication breakdowns are coped with, and consider how to employ their linguistic repertories in multilingual communication (Cogo \& Dewey, 2012; Galloway, 2017; Jenkins et al., 2011; Seidlhofer, 2011; Widdowson, 2012). Some researchers have suggested well-developed ELF corpora as suitable references in designing ELF-informed materials (Flowerdew, 2012; Kohn, 2015; Pedrazzini, 2015). To examine the suitability and practicality of the designed ELF- 
informed teaching materials, Galloway (2017) recommended the use of Tomlinson's (2011, p. 83) checklist, the criteria of which include 'expose the learners to language in authentic use', 'help learners to pay attention to features of authentic input', and 'provide the learners with opportunities to use the target language to achieve communicative purposes'.

Since the global spread of English has complicated the relationship between English and culture (Baker, 2015; Fang, 2018; Kirkpatrick, 2006), a straightforward correlation between English and cultures of Inner Circle countries is simplistic (Baker, 2011; Kachru, 1990). Therefore, cultural diversity in learning materials has been as equally emphasized as linguistic diversity. It has been argued that native cultures, non-native cultures and learners' own cultures should all be included (Galloway, 2017; Marlina, 2017; McKay, 2018; Wen, 2012; Xu \& Sharifian, 2017). By doing so, learners could develop awareness of cultural differences, critically approach them and respect the differences (Baker, 2012; Kirkpatrick, 2012; Matsuda, 2018; McKay, 2002).

The situation remains, however, that 'the prevailing orientation in ELT materials still remains undoubtedly towards ENL' (Jenkins, 2012, p. 489). The possibility of incorporating WE and ELF-informed learning materials is still under discussion and needs serious attention if WE and ELF research is to lead to pedagogical changes in ELT (Galloway, 2017). This study aims to contribute to the discussion of what 'English' should be presented to learners by investigating how Chinese English learners perceive ENL, ELF and WE-informed materials.

\section{The study}

This study is a part of a large ongoing project into the practicality of a pluricentric approach to teaching in China's Business English Program, a nationwide four-year undergraduate programme. The Chinese Business English Program is one of three national English-based programmes, along with the English Program and the Translation Program. The Business English Program was first established in 2007 to meet the demand of competent English users in the international business arena (Wang, Ye, Yan, Peng, \& Xu, 2015). With its international business orientation, the programme 
aims to prepare learners to communicate in a global multilingual context (Wu, 2016). The programme's rationale indicates that it should highlight linguistic and cultural diversity, which makes it a logical start to investigate the practicality of WE and ELFinformed learning materials.

In this project, business English students, business English teachers and business people were the main research subjects and data were collected through questionnaires, semi-structured interviews and classroom observations. The data presented here are from the questionnaire and semi-structured interviews targeted at students, and attempt to answer the following research questions:

(1) How do students perceive the current teaching materials in use? Are they ENL informed, WE informed or ELF informed, or some combination of these?

(2) How do students perceive the relative practicality of ENL, WE and ELF informed teaching materials?

The nine questionnaire items reported in this study were designed to investigate the linguistic and cultural diversity in the current learning materials. To answer the questionnaire, students were asked to rank the statements, from one to five, representing from 'strongly agree', 'agree', 'no opinion', 'disagree' to 'strongly disagree'. In total, 216 respondents returned the questionnaires. After screening, 207 (around 96\%) questionnaires were accepted for analysis while nine were excluded due to incomplete answers.

The questionnaire survey was followed by a series of semi-structured interviews, among which three were one-to-one interviews and three were focus group interviewees. The number of interviewees in each focus group varied from two to seven. In total, 15 students participated in interviews. The interviewees were numbered from S1 to S15 according to the sequence in which they were interviewed. All of the interviews were loosely guided by a number of pre-set questions. The interviews were conducted in Chinese Mandarin as this is the shared mother tongue of both interviewers and interviewees. 


\section{Findings}

\subsection{The questionnaire data}

As shown in Table 1 , more than $95 \%$ of respondents strongly agreed or agreed that British and American were two major varieties of English in their learning materials while fewer than $10 \%$ of respondents felt that China English or other varieties of English had been incorporated in the materials. This suggests that most respondents believe their learning materials are ENL informed, which supports the findings of much textbook analysis (e.g., Kopperoinen, 2011; Matsuda, 2002; Tomlinson \& Masuhara, 2013).

Table 1 Chinese business English majors'perceptions towards the linguistic diversities in their learning materials

\begin{tabular}{llllllll}
\hline Questions & $1(\%)$ & $2(\%)$ & $3(\%)$ & $4(\%)$ & $5(\%)$ & Mean & SD \\
\hline Q1 & 82.12 & 13.04 & 4.83 & 0 & 0 & 1.23 & 0.52 \\
Q2 & 0.48 & 6.76 & 22.70 & 24.63 & 45.41 & 4.08 & 0.99 \\
Q3 & 0.96 & 7.72 & 19.80 & 27.53 & 43.96 & 4.06 & 1.02 \\
Q4 & 7.72 & 13.52 & 23.18 & 24.63 & 30.91 & 3.57 & 1.27 \\
Q5 & 0 & 0 & 9.66 & 28.98 & 61.35 & 4.52 & 0.67 \\
Q6 & 4.83 & 12.56 & 25.60 & 26.08 & 30.91 & 3.66 & 1.18 \\
\hline
\end{tabular}

Note: $1=$ strongly agree, $2=$ agree, $3=$ no opinion, $4=$ disagree, $5=$ strongly disagree, $\mathrm{SD}=$ standard deviation

Q1 British and American English are the major varieties of English used in our textbooks

Q2 China English has been incorporated into our textbooks

Q3Other varieties of nativized English exist in our text books

Q4 Cases and examples in our text books include people with different mother tongues using English in business English settings.

Q5 Cases and examples in our text books include linguistic features different from British and American English are employed in business English settings.

Q6 Cases and examples in our text books include how to cope with communication breakdowns in business settings.

Table 1 also indicates that only around $20 \%$ of respondents thought that their learning materials included cases and examples where business people with different mother tongues use English, while over 55\% of respondents expressed the opposite idea. Respondents' perceptions towards the existence of linguistic features other than British and American English were convergent, with over 90\% of respondents choosing 
'disagree' or 'strongly disagree'. Also, fewer than $20 \%$ of respondents thought that their learning materials included cases and examples which demonstrated the use of communication strategies, while over half held the opposite opinion. It is interesting to note that, although a noticeable number of respondents reported the inclusion of ELF scenarios in their learning materials, none suggested the existence of the non-native use of English in the materials, thereby overlooking the ad hoc and creative use of English that is well attested in ELF communication (Cogo \& Dewey, 2012; Pitzl, 2017; Ranta, 2017; Seidlhofer, 2011). This raises questions about whether the ELF scenarios are really representative of ELF. This point will be discussed in the analysis of the interview data.

As suggested in Table 2, the vast majority of respondents thought that the materials strongly reflected cultures of native English-speaking countries. The figure decreased to around $16 \%$ and $12 \%$ when it came to Chinese culture and cultures of other nonnative English-speaking countries respectively. The figures suggest that the cultures of Inner Circle countries dominate the learning materials (supporting Lee, 2009; Matsuda, 2002) while Chinese culture and cultures of other non-native speaking countries were marginalized (supporting Liu \& Fang, 2017).

Table Two Chinese business English majors 'perceptions towards the cultural diversity in their learning materials

\begin{tabular}{llllllll}
\hline Questions & $1(\%)$ & $2(\%)$ & $3(\%)$ & $4(\%)$ & $5(\%)$ & Mean & SD \\
\hline Q7 & 66.18 & 23.18 & 10.14 & 0.48 & 0 & 1.45 & 0.69 \\
Q8 & 3.38 & 13.04 & 24.63 & 33.81 & 25.12 & 3.64 & 1.10 \\
Q9 & 1.44 & 11.11 & 25.60 & 29.46 & 32.36 & 3.80 & 1.06 \\
\hline
\end{tabular}

Note: $1=$ strongly agree, $2=$ agree, $3=$ no opinion, $4=$ disagree, $5=$ strongly disagree, $\mathrm{SD}=$ standard deviation

Q7Our teaching materials well reflect cultures of native English-speaking countries Q8Our teaching materials well reflect the Chinese culture.

Q9Our teaching materials well reflect cultures of other non-native English-speaking countries.

The questionnaire results illustrated in these two tables collectively suggest that there is no significant move to include linguistic and cultural diversity. In general, respondents saw the materials as ENL informed with rare references to WE and ELF. The following section will report how learners perceived the appropriateness of ENL- 
informed materials and how they perceived the practicality of incorporating WE and ELF-informed materials.

\subsection{The interview data}

\subsubsection{ENL-informed materials are essential}

Generally, interviewees expressed positive attitudes towards ENL and ENL-informed materials, which accords with much attitudinal research in various contexts $(\mathrm{He} \& \mathrm{Li}$, 2009; McKenzie, 2010: Ranta, 2010; Snodin \& Young, 2015; Wang \& Jenkins, 2016). The interview data further reveal that these positive attitudes resulted from two functional considerations. The first functional consideration is related to the issue of intelligibility. To take the following excerpt as an example:

S1: I do not like the Chinese accent at all. In communications, the more standard your English is, the easier that your English is understood.

R: Do you think that American English and British English have the highest intelligibility?

S1: Yes, absolutely. British and American English have the highest intelligibility on every occasion. Non-native varieties of English, such as Indian English, make me feel uncomfortable. It is hard to understand it. However, it is much easier to understand American English or British English due to their high intelligibility. Personally, I prefer the American accent than the British accent as the British accent is too flat.

S2: Um, I think so. There are some problems about my accent. Since we are learning Standard English, we are familiar with it and are thus able to understand it. I like American English and I am working hard to sound like an American person.

In this excerpt, interviewees stated that native-speaker Standard English is the most intelligible and that non-native linguistic features impede intelligibility in communication. They regarded native English speakers as providers of the most 
intelligible English and expressed negative attitudes towards non-native accents and also non-native varieties of Englishes, including China English. They perceived American English as a prestige variety of English and took its speakers as learning models. Despite convincing arguments on the creative use of English (Cogo \& Dewey, 2012; Liang \& Li, 2017; Pitzl, 2017), this study, as well as many others, has consistently reported bias against the intelligibility of 'non-native' varieties of English (Chan, 2018; He \& Zhang, 2010; Jenkins, 2007; McKenzie, 2008; Ren, Chen, \& Lin, 2016; Wang, 2013; Wang \& Jenkins, 2016). Wang and Jenkins (2016,) argued that 'attitudes towards users of certain forms can influence the evaluation of the forms in terms of their intelligibility. It is therefore implausible that intelligibility is exclusively tied up with native English' (p. 52). That is to say, intelligibility is largely a matter of people's understanding of what is or is not intelligible. Wang (2013) argued that 'ELT serves as a mechanism to develop and reinforce the participants' aspirations for ENL and, on the other hand, discourages their options for creative forms in English' (p. 271). Therefore, ENL-informed materials, as the most important resources of language input in classrooms, impact learners' attitudes towards intelligibility and develop and enhance their aspiration towards ENL.

The other functional consideration is about establishing the identity of being English majors. As suggested in the following two excerpts, interviewees believed that speaking native-like English is a way to express their identities as better English learners and speakers than non-English majors:

S15: I think accent does not necessarily influence communication. However, we are English majors. It is better to speak like native speakers ... Our English has to be better than non-English majors to prove our identity as English majors.

S7: I think as English majors, our English should be better than non-English majors. We should let people feel that we English majors by standardizing and polishing our English. By doing so, it would be easier for us to find jobs. 
In this excerpt, S15 intended to 'speak like native speakers' to prove her identity and S7 mentioned 'standardizing and polishing' his English to indicate that he is an English major. Since the time English became a compulsory subject from primary school (Hu, 2008), a Chinese student has learnt English for at least nine years before he/she enters the higher education system (Wen, 2012). As a consequence, China has a large number of English learners, the majority of whom are non-English majors. To compete with these non-English majors, interviewees, as English majors, were more likely to aspire to native English speaker norms. In these two statements, acquiring native-like English was believed necessary by S15 and S7 to secure their identity as English majors.

Interestingly, it is the global spread of English that has provided the catalyst for studies of WE and ELF, which have problematized the prestigious status of ENL in ELT (Jenkins, 2012; Kachru \& Nelson, 2006; Kirkpatrick, 2006; Ortega, 2014). It is also the global spread of English that has contributed to the unprecedented status of English in China (Gil \& Adamson, 2011). This has raised the 'standards' bar of being English majors and consequently reinforced the prestigious status of ENL among English majors.

By associating ENL with better employment, the statement made by S7 also supports ENL 'as the socially preferred English' (Wang, 2013, pp. 270-271). It seems that how a local context values different variety of English and how it expects and evaluates the performance of English learners and English majors influence learners' attitudes towards what they should learn in classrooms and what should be included in their learning materials.

\subsubsection{WE-informed materials are necessary at the advanced level}

This section reports the prospect of incorporating WE into learning materials. In the following excerpt, S4 - supported by S3 - proposed that other varieties of English including China English could be included into learning materials, but not before they have learnt American English or British English well: 
S4: Given that we have not acquired British English or American English well, it is not the time for China English to be included in learning materials.

S3: Um, I think we need to learn American English or British English first to build a solid foundation although I have a high acceptance to China English or other non-native varieties of English.

Interviewees' statements resonate with Wen's (2012) argument about the choice of linguistic variety in reference to learners' proficiency. Wen (2012) stipulated that native varieties, non-native varieties and the local variety of English should be offered to learners sequentially in relation to their English proficiency. By doing so, learners will be able to comprehend the common core, native varieties of English before they are able to use nativized features. To incorporate nativized features of China English into learning materials, He and Li (2009) underscored the importance of research that codifies salient linguistic features of China English. Ma and Xu (2017) argued that the progressive codification of the linguistic features of China English has proved that China English is developing to become a dynamic nativized variety of English. However, considering the complexity of pedagogical choices in countries in the Expanding Circle, the inclusion of China English into learning materials needs more than linguistic codifications. As Kirkpatrick (2006, p. 71) argued, the pedagogical choices are based on 'political and ideological grounds' as well as linguistic considerations.

One socio-political aspect, suggested by S3 in the following excerpt, is the power and influence of China. The interviewee emphasized that whether China English could be included in learning materials depends on the status of China English, which is determined by the economic advancement of China:

S3: I think whether China English should be included depends on the economic development of China. We have so many people learning English. I think, if China becomes stronger and stronger, China English would be widely accepted. 
The reason why English is used as a lingua franca is that America is a superpower country. If China is more influential, Chinese would be used as lingua franca, not just China English.

Despite envisaging a promising prospect of China English with the growing influence of China, this excerpt points to the inequalities of different varieties of English. Although in the academic literature of WE, researchers have been fighting for equality among different varieties of English (Kachru \& Nelson, 2006; Kirkpatrick, 2010), bias seems unavoidable in the socio-cultural landscape. Park and Wee (2009) approached the bias and inequalities with the notion of the linguistic market. They contended that in the linguistic market different varieties of English are attributed hierarchical values, with 'Inner Circle' varieties having the highest values, followed by 'Outer Circle' and 'Expanding Circle' varieties. This argument is echoed in this excerpt with interviewee S3 attributing American English, a representative of 'Inner Circle' varieties of English, higher value than China English, a representative of 'Expanding Circle' varieties. It seems that the learners' understanding that there are inequalities among Englishes influences their attitudes towards the practicality of employing WE-informed materials in the Chinese context.

\subsubsection{Inauthentic ELF scenarios under the umbrella of ENL-informed materials}

It is noteworthy that all interviewees unanimously agree with the changing role of ELF but note that this changing role is not well reflected in their learning materials, except for some pioneering initiatives in listening courses:

R: Do cases and examples in the learning materials include people with different mother tongues using English to communicate?

S4: Well, only a few in listening courses. Our teacher once presented us with a video of people with different first languages using English to communicate. We thought their accents were funny and laughed. We did not consider and take the 
scenario seriously. We should have thought that there are many different varieties of English and English is a not always the same like we have learned in classrooms.

S5: Um, I want to know how people with different mother tongues use English to communicate but I do not know how I can make it.

S3: yes, if our school does not offer the related knowledge, it is hard for us to get informed.

In this excerpt, S4 recalled a scenario where ELF-informed listening materials were employed in a listening lecture. However, as S4 suggested, the ELF-informed listening materials were treated as entertainment through the non-native accents rather than insightful examples informing learners how English is creatively and productively used in multilingual settings. S5 and S3 continued the dialogue by raising their concerns about a lack of other linguistic and para-linguistic ELF-informed knowledge in addition to 'accents'. Although the teacher's intention in using the video is unknown, the use of this video unfortunately did not inspire students to think about how English works as a lingua franca.

Some interviewees suggested the need for ELF-informed activities. For instance:

S2: I think English is a communication tool.

S1: yes, it is a communication tool. Now it is a lingua franca, a most commonly used language. For example, in a business conference, two business people with different first languages will definitely choose English to communicate to avoid language barriers.

$[\ldots]$

S2: In every chapter in our business English textbook, there are group work and case studies to simulate the business contexts. . .I think in a real business context, the accuracy of grammar is very important ... We just imagined what they should look like. For instance, we do not how business people from a specific country 
use English to communicate in a business meeting. We do not have references.

In this excerpt, English as a communication tool was proposed by $\mathrm{S} 2$ and reiterated by S1, who then clearly specified the role of ELF in business contexts. S1 noted that the group work and case studies in their materials were intended to simulate authentic English as business lingua franca settings but unfortunately lack references about how English really works as a lingua franca in the settings. It seems that the rare references to ELF not only impeded interviewees' effective use of the activities but enhanced their belief in the importance of grammatical accuracy in ELF settings. This might explain why in the questionnaire survey over $20 \%$ respondents reported the inclusion of ELF scenarios, but none suggested the existence of non-standard linguistic features in their learning materials.

To be authentic, ELF settings need the authentic use of English in these settings. There is a substantial body of work pointing out the ad hoc, dynamic and creative use of English in authentic ELF settings (Cogo \& Dewey, 2012; Jenkins et al., 2011; Rogerson-Revell, 2010; Seidlhofer, 2011). The findings of all this research have confirmed that although the use of ELF does not follow native English norms, it does not necessarily cause communication breakdowns. Seidlhofer (2015) argued that ELF informed activities should facilitate learners to connect English learning to the experience of their first language and be aware of 'how linguistic forms are in general determined by communication functions' (p. 26). The activities in the learning materials identified by interviewees obviously fail to achieve this.

The contextualization of ELF in ENL-informed materials may be intended to reflect the global spread of English. However, without mentioning how ELF users adapt their English in their own ways to meet their own communication purposes, this inclusion of ELF settings is inauthentic and misleading. 


\subsubsection{Native cultures, non-native cultures and learners' home culture should all be included}

In contrast with various considerations about linguistic representations in learning materials, interviewees unanimously agreed that cultural representations should be diversified. Although it is unrealistic to include all of the cultural representations, the awareness and knowledge of cultures beyond American and British cultures is crucial (Matsuda, 2018). In the following excerpt, the two interviewees emphasized the importance of Chinese culture, which they feel takes up a much smaller proportion than American and British cultures in the current learning materials:

S1: Our textbooks mainly represent American and British cultures. I think knowledge about Chinese culture is too limited. Chinese culture should enrich the textbooks. There is nothing about Chinese culture in the last two textbooks that I have studied. Chinese culture is very important, especially at the time when China is actively involved in globalization.

S2: Um, um.

The lack of Chinese culture in English learning materials may be the result of so-called 'Chinese Culture Aphasia' (中国文化失语症) (Wen, 2016; Xiao, Xiao, Li, \& Song, 2010). The phrase refers to Chinese English users' failure to properly explain Chinese cultural concepts in English in intercultural communications (Xue \& He, 2017). As early as the beginning of this century, Cong (2000) declared that, with the dominance of American and British cultures, Chinese culture was generally absent in English. This situation seems to not have changed, even though the need for the promotion of Chinese culture and learners' intercultural competence have been mentioned in almost every national English curriculum reform across different levels in the last two decades (Chen \& Gu, 2008; Cheng, 2004; Cheng \& Dan, 2012; Wang, 2016; Wen, 2012).

Moreover, interviewees have highlighted the necessity to connect foreign cultures to Chinese culture: 
S5: culture learning is as important as language learning. It would be more interesting to include different cultures.

S3: yeah, for example, the first unit in our textbook is about the life of freshmen in universities in America. We were once freshmen. But it does not inform us how they get enrolled in a university and what the differences between them and us are. . .I am still confused. We learned a story and then the lecture finished.

S4: Um, articles in the textbook used in our Comprehensive English are all written by foreigners, who barely know what we are thinking about.

In this excerpt, S5 accentuates the importance of cultural learning and suggests the inclusion of cultural diversity in learning materials. Her suggestion was supported by S3, who identified the failure to highlight differences between American culture and Chinese culture in the current materials. S4 attributed the failure to the exclusiveness of literature written by non- Chinese writers. What is emphasized here is similar to the concept of interculturality that refers to 'learners' ability to reflect on their own culture by comparing it with other cultures' (McKay, 2002, p. 82). It is to establish a sphere of interculturality that researchers highlight the importance of cultural diversity in learning materials (Baker, 2011; McKay, 2018; Xu \& Sharifian, 2017). This calls for the inclusion of native speakers' cultures, learners' home culture and other non-native speakers' cultures into learning materials (Baker, 2015; Galloway, 2017; Kirkpatrick, 2012; Matsuda, 2012a, 2012b, 2018; Wen, 2016).

\section{Discussion}

The questionnaire data demonstrate that the popularity of ENL-informed materials remains and there is no significant change in the inclusion of WE and ELF-informed materials. The interview data suggest two important aspects behind learners' perceptions towards ENL, WE and ELF-informed materials; that is, the power and the authenticity of the 'English' that each type of material represents.

Interviewees attributed the power of a particular variety of English to the power of 
the nation that speaks this variety of English. As American English, a representative of ENL, was regarded as powerful as America, interviewees expressed their preference for ENL and ENL-informed materials. As Bolton (2018) commented, 'the power of the US variety of English continues to parallel the continuing economic, cultural, military and political power of the United States in many other spheres worldwide' (p. 10). The power of ENL manifests in its social preference in the Chinese context where it is expected that English majors would acquire better English than non-English majors. This explains why the English major interviewees defined acquiring ‘better English’ as acquiring native-like English, as they felt that this would empower them to compete successfully against non-English majors in the job market. The power of ENL is also used by interviewees to measure the status of emerging varieties of English and thus to determine whether they should be included in learning materials. Despite interviewees' aspiration for ENL and preference for ENL-informed materials, this study among other recent studies has suggested a promising prospect of incorporating China English into ELT (He, 2017; Marlina, 2017). A positive attitude can be seen through interviewees' suggestion to include China English into learning materials at the advanced level. However, this study found that the positive attitude is not due to the interviewees' awareness of the equality among different varieties of English. It is due to interviewees' perception that the power of China English is increasing with the growing influence of China. In other words, interviewees thought that China English should not be incorporated into learning materials until they have learnt ENL well and/or until China English is as powerful as ENL.

It is interesting to note that interviewees define both English majors' English and China English in relational terms: how English majors' English stands in contrast with that of non-English majors' and how China English stands in contrast with Inner Circle varieties of English. The two relational terms suggest the prestige status of ENL and also bias towards other varieties of English. Interviewees' perceptions towards imbalanced power among different varieties of English embodies the 'language ideology that constitutes and reflects the biases people have toward linguistic varieties 
and speakers' race/ ethnicity', which was argued to be 'the major obstacle in pedagogical implementation of world Englishes' (Kubota, 2018, p. 97).

The other noteworthy aspect is the issue of authenticity. Research on WE and ELF has complicated the issue of authenticity and has brought new perspectives in the 'authenticity' debate (Mishan, 2005). Although the 'authenticity' of learning materials is a shared concern of both SLA/EFL and WE/ELF researchers, they have different interpretations towards it. In SLA/EFL, the term 'authenticity' is often employed to refer to ENL, its speakers and cultures. Thus, authentic materials are ENL-informed materials (Lowe \& Pinner, 2016), as also suggested by some interviewees in this study. However, WE and ELF researchers argued that authentic materials should be defined in reference to the use of language in bi/multilingual situations where English is used differently from standardized ENL but able to achieve communicative success (Galloway, 2017; Kirkpatrick, 2012). As Pinner (2016) noted, it is problematic to equalize ENL with authenticity, and the traditional way of 'mak[ing] specific reference to English native speakers as a measure for sociopragmatic communicative competence' (p. 88) should be revisited. Although SLA/EFL and WE/ELF researchers have not convinced each other on the issue of authenticity, it appears that the simulated ELF scenarios in ENL-informed materials do not represent the authentic use of ELF. Inauthentic simulated ELF scenarios might provide learners with a misleading impression that all English users in bi/multilingual contexts speak the same way as native English speakers. This finding warrants serious attention and further research is welcome to support it.

\section{Conclusion}

This article demonstrates how Chinese English learners perceive ENL, WE and ELF informed materials. The questionnaire data and interview data have yielded a number of findings, which have implications for ELT materials.

To enable learners to develop language attitudes that are congruent to the current status of English, its users and cultures, it is important to consider the pedagogical implications of WE and ELF research in the design of new ELT materials in the Chinese 
context. WE and ELF research has illustrated how English is creatively used in local and global contexts, and the ways in which it differs from the ways that native English speakers use English. Therefore, materials designers should be careful with the issues of power and authenticity when they refer to the global use of English. It is important to provide contexts of the global spread of English, which could raise learners' awareness of the globalization of English. It is also important to inform how English is used in local and global contexts, which could raise learners' awareness of linguistic and cultural diversity.

Interestingly, despite interviewees' aspiration for ENL, they dissociated English language from its Anglo-American cultural roots. They reported the necessity of adding the Chinese culture and cultures of other non-native English varieties, which are currently ill represented in their learning materials. This manifests a straightforward clash between a linguistic attachment to ENL and a cultural detachment from the traditional native-English speaking countries. It suggests the possibility and practicality of enriching cultural contents in learning materials, which represent the cultural diversity and could in turn enhance learners' understanding about linguistic diversity.

Since language teaching is always context bound, Chinese researchers and teachers should be more familiar with what Chinese English learners need to communicate in local and global contexts and what materials could prepare learners to communicate in local and global contexts. It is thus important for Chinese researchers and practitioners to actively engage in designing Chinese context-informed materials or adapting imported materials for its better use in the Chinese context.

It is worth pointing out the limitations of this study in that it only reports on business English learners' voices. The findings from questionnaires and interviews could be triangulated with textbook analysis. In addition, to explore how the materials are actually used and implemented in business English classrooms, a classroom observation is necessary. 


\section{Acknowledgments}

I would like to thank the three reviewers and the editors for their insightful feedback.

My gratitude also goes to Professor Andy Kirkpatrick for his invaluable suggestions and comments.

\section{Disclosure statement}

No potential conflict of interest was reported by the author.

\section{Funding}

This work was supported by the China Scholarship Council (CSC) and Griffith University $\mathrm{PhD}$ Scholarships.

\section{ORCID}

Jinghui Si http://orcid.org/0000-0002-7600-0547

\section{References}

Baker, W. (2011). Intercultural awareness: Modelling an understanding of cultures in intercultural communication through English as a lingua franca. Language and Intercultural Communication, 11(3), 197-214.

Baker, W. (2012). From cultural awareness to intercultural awareness: Culture in ELT. ELT Journal, 66(1), 62-70.

Baker, W. (2015). Culture and identity through English as a lingua franca: Rethinking concepts and goals in intercultural communication. Berlin: De Gruyter Mouton.

Bolton, K. (2006). Chinese Englishes: A sociolinguistic history. Cambridge: Cambridge University Press.

Bolton, K. (2018). World Englishes and second language acquisition. World Englishes, 37(1), 5-18.

Bolton, K., Botha, W., \& Zhang, W. (2015). English in China: A contemporary bibliography. World Englishes, 34(2), 282-292.

Chan, J. Y. H. (2018). Gender and attitudes towards English varieties: Implications for teaching English as a global language. System, 76, 62-79.

Chen, J., \& Gu, Z. (2008). 要求更完善, 方向更明晰一一对 07 版《大学英语课 程教学要求》的新解读. [More reasonable and precise requirements with realizing directions — interpreting the 2007 college English curriculum requirements]. Computer-assisted Foreign Language Education, (1), 3-8.

Cheng, X. (2004). 《普通高中英语课程标准(实验)》解读. [Interpretations of the English Curriculum for senior high school (the trial version)]. Journal of Basic English Education, 6(3), 3-8. 
Cheng, X., \& Dan, W. (2012). 基础教育阶段英语课程的核心理念解读. [Interpretations on the core rationale of English curriculum of basic education]. Curriculum, Teaching Material and Method, 32(3), 57-63.

Cogo, A., \& Dewey, M. (2012). Analysing English as a lingua franca: A corpus-driven investigation. London: Continuum.

Cong, C. (2000, October 19). "中国文化失语症": 我国英语教学的缺项. [Chinese Culture Aphasia: Weaknesses in English teaching in China]. Guangming Daily.

Crystal, D. (2006). English worldwide. In R. Hogg \& D. Denison (Eds.), A history of the English language (pp. 420-439). Cambridge: Cambridge University Press.

Crystal, D. (2008). Two thousand million? English Today, 24(1), 3-6.

D’Angelo, J. F. (2005). Educated Japanese English: Expanding oral/aural core vocabulary. World Englishes, 24(3), 329-349.

De Costa, P. I., \& Crowther, D. (2018). Second language acquisition and world Englishes: Dialogue and engagement. World Englishes, 37(1), 19-33.

Dogancay-Aktuna, S., \& Hardman, J. (2018). Teaching of English as an international language in various contexts: Nothing is as practical as good theory. RELC Journal, 49(1), 74-87.

Fang, F. (2018). Ideology and identity debate of English in China: Past, present and future. Asian Englishes, 20(1), 15-26.

Flowerdew, J. (2012). Corpora in language teaching from the perspective of English as an international language. In L. Alsagoff, S. L. McKay, G. Hu, \& W. R. Renandya (Eds.), Principles and practices for teaching English as an international language (pp. 226-243). New York: Routledge.

Galloway, N. (2017). ELF and ELT teaching materials. In J. Jenkins, M. Dewey, \& W. Baker (Eds.), The Routledge handbook of English as a lingua franca (pp. 570582). Abingdon: Routledge.

Gil, J., \& Adamson, B. (2011). The English language in mainland China: A sociolinguistic profile. In A. Feng (Eds.), English language education across greater China (pp. 23-45). Bristol: Multilingual Matters.

He, D. (2017). Perceptions of Chinese English and pedagogic implications for teaching English in China. In Z. Xu, D. He, \& D. Deterding (Eds.), Researching Chinese English: the state of the art (pp. 127-140). Cham: Springer International Publishing AG.

He, D., \& Li, D. (2009). Language attitudes and linguistic features in the 'China English' debate. World Englishes, 28(1), 70-89.

He, D., \& Zhang, Q. (2010). Native speaker norms and China English: From the perspective of learners and teachers in China. TESOL Quarterly, 44(4), 769-789.

Hu, Y. (2008). China's English language policy for primary schools. World Englishes, 27(3-4), 516-534.

Jenkins, J. (2006). Current perspectives on teaching world Englishes and English as a lingua franca. TESOL Quarterly, 40(1), 157-181.

Jenkins, J. (2007). English as a lingua franca: Attitude and identity. Oxford: Oxford University Press.

Jenkins, J. (2012). English as a lingua franca from the classroom to the classroom. ELT 
Journal, 66(4), 486-494.

Jenkins, J. (2015). Repositioning English and multilingualism in English as a lingua franca. Englishes in Practice, 2(3), 49-85.

Jenkins, J., Cogo, A., \& Dewey, M. (2011). Review of developments in research into English as a lingua franca. Language Teaching, 44(3), 281-315.

Kachru, B. B. (1990). The alchemy of English: The spread, functions, and models of non-native Englishes. Illinois: University of Illinois Press.

Kachru, Y., \& Nelson, C. L. (2006). World Englishes in Asian contexts. Hong Kong: Hong Kong University Press.

Kirkpatrick, A. (2006). Which Model of English: Native-speaker, Nativized or lingua franca. In R. Rubdi \& M. Saraceni (Eds.), English in the world: Global rules, global roles (pp. 71-83). London: Continuum.

Kirkpatrick, A. (2010). The Routledge handbook of world Englishes. New York: Routledge.

Kirkpatrick, A. (2012). English as an Asian Lingua Franca: the 'Lingua Franca Approach' and implications for language education policy. Journal of English as a Lingua Franca, 1(1), 121-140.

Kirkpatrick, A., \& Xu, Z. (2002). Chinese pragmatic norms and 'China English'. World Englishes, 21(2), 269-279.

Kohn, K. (2015). A pedagogical space for ELF in the English classroom. In Y. Bayyurt \& A. Sumru (Eds.), Current Perspectives on Pedagogy for English as a Lingua Franca (pp. 51-67). Berlin: De Gruyter.

Kopperoinen, A. (2011). Accents of English as a lingua franca: a study of Finnish textbooks. International Journal of Applied Linguistics, 21(1), 71-93.

Kubota, R. (2018). Unpacking research and practice in world Englishes and Second Language Acquisition. World Englishes, 37(1), 93-105.

Lee, K.-Y. (2009). Treating culture: What 11 high school EFL conversation textbooks in South Korea do. English Teaching, 8(1), 76-96.

Li, D. C. (2007). Researching and teaching China and Hong Kong English. English Today, 23, 11-17.

Liang, J., \& Li, D. C. S. (2017). Researching collocational features: Towards China English as a distinctive new variety. In X. Zhichang, D. He, \& D. Deterding (Eds.), Researching Chinese English: the state of the art (pp. 61-76). Cham: Springer International Publishing AG.

Liu, J., \& Fang, F. (2017). Perceptions, awareness and perceived effects of home culture on intercultural communication: Perspectives of university students in China. System, 67, 25-37.

Lowe, R. J., \& Pinner, R. (2016). Finding the connections between native-speakerism and authenticity. Applied Linguistics Review, 7(1), 27-52.

Ma, Q., \& Xu, Z. (2017). The Nativization of English in China. In Z. Xu, D. He, \& D. Deterding (Eds.), Researching Chinese English: the State of the Art (pp. 189-201). Cham: Springer International Publishing AG.

Marlina, R. (2017). The prospect of teaching English as an international language in a Chinese context: Student-teachers' reactions. In Z. Xu, D. He, \& D. Deterding 
(Eds.), Researching Chinese English: The state of the art (pp. 173-188). Cham: Springer International Publishing AG.

Matsuda, A. (2002). Representation of users and uses of English in beginning Japanese EFL textbooks. JALT journal, 24(2), 182-200.

Matsuda, A. (2003). Incorporating world Englishes in teaching English as an international language. TESOL Quarterly, 37(4), 719-729.

Matsuda, A. (2012a). Principles and practices of teaching English as an international language. Bristol: Multilingual Matters.

Matsuda, A. (2012b). Teaching materials in EIL. In L. Alsagoff, G. Hu, \& W. A. Renandya (Eds.), Principles and practices for teaching English as an international language (pp. 168-185). New York: Routledge.

Matsuda, A. (2018). Is Teaching English as an International Language All about Being Politically Correct? RELC Journal, 49(1), 24-35.

McKay, S. L. (2002). Teaching English as an International Language: Rethinking Goals and Perspectives. Oxford: Oxford University Press.

McKay, S. L. (2018). English As an International Language: What It Is and What It Means For Pedagogy. RELC Journal, 49(1), 9-23.

McKenzie, R. M. (2008). Social factors and non-native attitudes towards varieties of spoken English: A Japanese case study. International Journal of Applied Linguistics, 18(1), 63-88.

McKenzie, R. M. (2010). The social psychology of English as a global language: Attitudes, awareness and identity in the Japanese context. Dordrecht: Springer.

Ortega, L. (2014). Ways forward for a bi/multilingual turn in SLA. In S. May (Eds.), The multilingual turn: Implications for SLA, TESOL and bilingual education (pp. 32-53). New York: Routledge.

Park, J. S.-Y., \& Wee, L. (2009). The three circles redux: A market-theoretic perspective on World Englishes. Applied Linguistics, 30(3), 389-406.

Pedrazzini, L. (2015). Raising trainee teachers' awareness of language variation through data-based tasks. In P. Vettorel (Eds.), New frontiers in teaching and learning English (pp. 77-101). Newcastle-upon-Tyne: Cambridge Scholars Publishing.

Pingali, S. (2009). Indian English. Edinburgh: Edinburgh University Press.

Pinner, R. S. (2016). Reconceptualising authenticity for English as a global language. Bristol: Multilingual Matters.

Pitzl, M.-L. (2017). creativities, idioms and metaphorical language in ELF. In J. Jenkins, M. Dewey, \& W. Baker (Eds.), The Routledge handbook of English as a lingua franca (pp. 233-243). Abingdon: Routledge.

Ranta, E. (2010). English in the real world vs. English at school: Finnish English teachers' and students' views. International Journal of Applied Linguistics, 20(2), 156-177.

Ranta, E. (2017). Grammar in ELF. In J. Jenkins, M. Dewey, \& W. Baker (Eds.), The Routledge handbook of English as a lingua franca (pp. 244-254). Abingdon: Routledge.

Ren, W., Chen, Y.-s., \& Lin, C.-Y. (2016). University students' perceptions of ELF in mainland China and Taiwan. System, 56, 13-27. 
Ren, W., \& Han, Z. (2016). The representation of pragmatic knowledge in recent ELT textbooks. ELT Journal, 70(4), 424-434.

Rogerson-Revell, P. (2010). "Can you spell that for us nonnative speakers?" Accommodation strategies in international business meetings. The Journal of Business Communication, 47(4), 432-454.

Seidlhofer, B. (2011). Understanding English as a lingua franca. Oxford: Oxford University Press.

Seidlhofer, B. (2015). ELF-informed pedagogy: From code-fixation towards communicative awareness. In P. Vettorel (Eds.), New frontiers in teaching and learning English (pp. 19-30). Newcastle-upon-Tyne: Cambridge Scholars Publishing.

Sherman, J. E. (2010). Uncovering cultural bias in EFL textbooks. Issues in Applied Linguistics, 18(1), 27-35.

Shin, J., Eslami, Z. R., \& Chen, W.-C. (2011). Presentation of local and international culture in current international English-language teaching textbooks. Language, Culture and Curriculum, 24(3), 253-268.

Snodin, N., \& Young, T. (2015). 'Native-speaker' varieties of English: Thai perceptions and attitudes. Asian Englishes, 17(3), 248-260.

Song, H. (2013). Deconstruction of cultural dominance in Korean EFL textbooks. Intercultural Education, 24(4), 382-390.

Spolsky, B. (2004). Language policy. Cambridge: Cambridge University Press.

Tan, R. S. K., \& Low, E.-L. (2014). Rhythmic Patterning in Malaysian and Singapore English. Language and Speech, 57(2), 196-214.

Taylor-Mendes, C. (2009). Construction of racial stereotypes in English as a Foreign Language (EFL) textbooks: Images as discourse. In R. Kubota \& A. Lin (Eds.), Race, culture, and identities in second language education (pp. 64-80). New York: Routledge.

Tomlinson, B. (2011). Materials development in language teaching. Cambridge: Cambridge University Press.

Tomlinson, B., \& Masuhara, H. (2013). Adult coursebooks. ELT Journal, 67(2), 233249.

Vettorel, P., \& Lopriore, L. (2013). Is there ELF in ELT coursebooks? Studies in Second Language Learning and Teaching, 3(4), 483-504.

Wang, L., Ye, X., Yan, M., Peng, Q., \& Xu, D. (2015). 商务英语专业本科教学质量 国家标准要点解读. [Interpretations of key points in national principles for the quality of the Business English Program]. Foreign Language Teaching and Research, (2), 297-302.

Wang, S. (2016). 《大学英语教学指南》要点解读. [Interpretations on the key points of the Guidelines on College English Teaching]. Foreign Language World, (3), $2-10$.

Wang, Y. (2013). Non-conformity to ENL norms: A perspective from Chinese English users. Journal of English as a Lingua Franca, 2(2), 255-282.

Wang, Y., \& Jenkins, J. (2016). "Nativeness" and intelligibility: Impacts of intercultural experience through English as a lingua franca on Chinese speakers' language 
attitudes. Chinese Journal of Applied Linguistics, 39(1), 38-58.

Wei, L. (2016). New Chinglish and the post-multilingualism challenge: Translanguaging ELF in China. Journal of English as a Lingua Franca, 5(1), 125.

Wen, Q. (2012). Teaching English as an international language in mainland China. In A. Kirkpatrick \& R. Sussex (Eds.), English as an international language in Asia: Implications for language education (pp. 79-93). Dordrecht: Springer.

Wen, Q. (2016). Teaching culture (s) in English as a lingua franca in Asia: Dilemma and solution. Journal of English as a Lingua Franca, 5(1), 155-177.

Widdowson, H. G. (2012). ELF and the inconvenience of established concepts. Journal of English as a Lingua Franca, 1(1), 5-26.

Wright, S., \& Zheng, L. (2017). Language as system and language as dialogic creativity: the difficulties of teaching English as a lingua franca in the classroom. In J. Jenkins, M. Dewey, \& W. Baker (Eds.), The Routledge handbook of English as a lingua franca (pp. 406-517). Abingdon: Routledge.

$\mathrm{Wu}$, J. (2016). 商务英语通用语: 商务英语教学的新视角. [English as Business Lingua Franca: new perspectives for teaching business English]. Contemporary Foreign Language Studies, (1), 48-52.

Xiao, L., Xiao, D., Li, L., \& Song, Y. (2010). 我国高校英语教育中的“中国文化失 语”现状研究. [A Study of the “Chinese Culture Aphasia” in Present English Education in Chinese Higher Education]. Foreign Language Learning Theory and Practice, (1), 39-46.

$\mathrm{Xu}$, Z. (2017). Developing meta-cultural competence in teaching English as an international language. In F. Sharifian (Eds.), Advances in cultural linguistics (pp. 703-720). Cham: Springer International Publishing AG.

$\mathrm{Xu}, \mathrm{Z}$. (2018). Exploring English as an International Language-Curriculum, Materials and Pedagogical Strategies. RELC Journal, 49(1), 102-118.

$\mathrm{Xu}, \mathrm{Z}$., \& Sharifian, F. (2017). Cultural conceptualisations in Chinese English: Implications for ELT in China. In Z. Xu, D. He, \& D. Deterding (Eds.), Researching Chinese English: the state of the art (pp. 205-208). Cham: Springer International Publishing AG.

Xue, F., \& He, S. (2017). 语言态度影响中国文化失语症的实证研究. [How language attitude influences Chinese culture aphasia: An empirical study]. Foreign Language and Literature Research, 3(3), 19-29.

Yim, S. (2007). Globalization and Language Policy in South Korea. In A. Tsui \& J. W. Tollefson (Eds.), Language policy, culture, and identity in Asian contexts (pp. 3753). Mahwah, NJ: Lawrence Erlbaum Associates. 